\title{
Implementation of Marine and Fisheries Business Actor Card Policy (KUSUKA) in West Aceh Region
}

\author{
M. Akbar Ichtiar, Nodi Marefanda ${ }^{\circledR}$, Nellis Mardhiah \\ Department of Public Administration, Universitas Teuku Umar, Indonesia
}

\begin{tabular}{l} 
ARTICLE INFORMATION \\
\hline Received: March 13, 2021 \\
Revised: March 20, 2021 \\
Accepted: March 28, 2021 \\
Available online: April 05, 2021 \\
KEYWORDS \\
\hline Implementation, KUSUKA Card \\
CORRESPONDENCE \\
\hline E-mail: nodimarefanda@utu.ac.id \\
\hline
\end{tabular}

\section{INTRODUCTION}

Excellent service is one of the most important things to consider in a government. Various efforts have been made by the government to achieve excellent service hoping that the services provided will be right on target. One of the service strategies practiced by the government in providing targeted services is usage of identity card. During the last 2 periods of Indonesian rule, usage of cards in public service is indeed a very identical thing, the government has so far issued many service cards including the Smart Indonesia Card (KIP), the Healthy Indonesia Card (KIS) and the Pre-Work Card (Prakerja).

Not only government in the public sector, but also specific sectors applied the same thing such as the Indonesian Marine and Fisheries sector (KP). The government through the Ministry of Marine Affairs and Fisheries (KKP) also has a main program in providing card-based services to the society called the Marine and Fisheries Business Actor Card (KUSUKA). Previously, in 2016 the KKP had also issued a fisherman card policy through Permen-KP Number 16 of 2016 but this policy still has shortcomings in terms of scope where the fisherman card only covers the fishing profession without covering other business actors in the KP sector. Based on this problem, the KKP in September 2017 replaced the fisherman card program into a KUSUKA card so that the scope of services to people who have professions in the KP sector can be expanded. From only applicable to people who work as fishermen, now the scope is expanded to include fish cultivators. fishery product producers and marketers. In other words, this policy covers all business actors in the KP sector, from upstream to downstream.

Some of the objectives of the KUSUKA card policy include improving service quality, simplifying data collection in one database in order to reduce data redundancy, increasing effectiveness and efficiency of the data collection program and budgeting problem, increasing cooperation with various partners and many other purposes.

Besides serves as an identity card for people who work in the KP sector, the KUSUKA card also functions as a tool in obtaining good services, protection, guidance and empowerment as well as a means of monitoring and evaluating programs from the KKP. Another function that makes it very easy for the community is the cooperation between the KKP and financial institutions such as Bank, so this card can also be used as a means of saving and borrowing money like an ATM.

Another advantage of this card is data integration. The integration of data between management agencies in the regions such as the Marine and Fisheries Service and Civil Registration Service agencies makes this program very good for avoiding data that is not concrete so that the level of data compatibility with real conditions in the field can be better and it will have a positive impact on data accuracy in order to give right-on-target service to society.

To get a KUSUKA card, the society can apply it online through the website www.satudata.kkp.go.id on the KUSUKA dashboard. The society can also come to the office of the West Aceh Regency Marine and Fisheries Service directly and bring administrative requirements such as a photocopy of the identity (KTP) and a letter from village government stating that the applicant is indeed working in the marine and fisheries sector for individual registrants and an additional photocopy of a taxpayer identification number (NPWP) for registrants who are group (corporation). The informations stated on the KUSUKA are 
personal data such as name, profession, address, identification number (NIK), validity period and QR code.

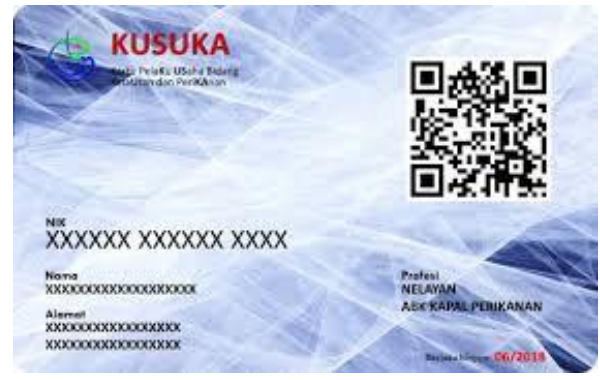

Picture 1. KUSUKA Card

Some of benefits that can be obtained by the community after having a KUSUKA card are making it easier for people to do online transaction because the KUSUKA card can also function as an ATM, making it easier for people to apply for insurance and People's Business Credit (KUR) in banks collaborated with KKP.

Officers who implement the KUSUKA card policy are called fishery extension agents who are scattered throughout Indonesia and assigned to the Marine and Fisheries Service (DKP) in each region. Fishery extension agents are a special unit formed and working directly under the coordination of the KKP and obliged to be responsible and report their performance not only to the KKP but also to the DKP as their place of duty. Fishery extension agents have several main tasks and functions (tupoksi), but in terms of the KUSUKA card policy, the fisheries extension agent is tasked with carrying out data collection, guidance, dissemination of KP policies, marketing guidance and so on related to business activities in the KP sector.

This program, which has the legal standing of PERMEN-KP Number 39 year 2017 concerning Marine and Fisheries Business Actor Cards has been running for more than 2 years, but so far there are still obstacles as stated in a study on the effectiveness of implementing the KUSUKA card in West Java (Daniarsyah, 2019) that the KUSUKA card is an effective data collection program but so far there are still problems in the distribution aspect.

These problems have similarity with the problems that occurred in Aceh Barat District. Based on the author's preliminary observations, not all people have the KUSUKA card and some people even admit that they don't know at all about what KUSUKA card is. The public's ignorance of course indicates there is a problem in its implementation.

Therefore, a scientific answer is needed to identify where the problem lies. Based on the discussion previously described, the authors are interested in conducting research by focusing on the aspect of implementing the KUSUKA Card policy and this research is located in West Aceh Regency.

Based on the focus and locus as well as the problems previously described, the question in this study is How the implementation of KUSUKA Card policy is running in West Aceh District?. This research was conducted with the aim of providing scientific answers which were presented in the form of analysis based on real data in the field related to the implementation of the KUSUKA Card policy.

\section{METHOD}

Based on focus of the problems studied, this study used a qualitative method with a descriptive approach. Qualitative research is research conducted by translating field findings into a value aimed at understanding in depth the complexity of social phenomena (Sugiyono, 2015) and the descriptive approach is a research approach by describing the results of the research in general way (Sugiyono, 2015). The reason why authors selected this method and approach are because this research requires descriptive answers with general studies related to the implementation of the KUSUKA policy in West Aceh.

In this study, the authors used two types of data sources as presented by (Sugiyono, 2015), namely:

1. Primary

Primary data is data that is found directly from the object of research in the field during the research process. This data is obtained from the process of interaction with the research objectives either from interviews or data from direct observation (observation) in the field. In this study, primary data was collected through a direct observation process at the West Aceh District Marine and Fisheries Office and interviews with informants consisting of officers (fisheries extension), Panglima Laot and the people of West Aceh who work in the marine and fisheries sector.

\section{Secondary}

Secondary data is indirect data obtained through intermediaries or documents related to research. Secondary data is intended to strengthen primary data with various media such as previous research, literature studies, supporting documents related to research focus and others.

In collecting data, the authors use methods by (Creswell, 2016) as following:

1. Observation

Observation is an initial observation activity that aims to find out general problems related to the object of research. This activity can be done by directly observing the activity/behavior in the field or by asking basic questions in accordance with the focus of the research.

2. Interview

Interview is question-and-answer activity between researchers and informants either in direct or indirect interaction through an intermediary such as mobile device. In this activity, the authors conducted face to face interactions with informants. In addition, if the required data is not sufficient, the authors contact the informants using a mobile device to collect additional data related to the research.

3. Documentation

Documentation is an activity to collect files such as reports, articles, news, letters and so on. In this study, the authors focused on collecting from internet media such as the KKP's official website and articles containing news related to the research focus.

4. Audio-Visual Material

Audio-Visual material is data that can be heard such as those from sound recordings or which can be seen such as those obtained from video recordings, images, digital applications and others. In this study, the authors used sound recordings taken during the interview process. 
In analyzing the data, the authors use the method of Miles and Huberman (1984) in Sugiyono (2015), as following:

1. Data Reduction

Data reduction is an analysis technique carried out by selecting the data needed and in accordance with the research focus and not using unnecessary data. At this stage, the authors collect rough data obtained during the research process in West Aceh then summarize the data and separate it into 2 groups of data, namely data that is entered into writing and those that are not included.

2. Display Data

After the data is reduced, the next step is Display data. At this stage, the authors present research data that have been through the process of reduction, then the authors present both in the form of text, charts, tables and graphs which will make it easier for the author to draw conclusions from the data obtained.

3. Conclusion Drawing

Conclusion drawing is an activity of translating data that have been reduced and presented into a conclusion. In carrying out this process, the authors review all existing data carefully in order to get a valid conclusion.

The research informants are determined using purposive sampling. Based on this technique, the informants in this study include Fisheries Extension unit of the West Aceh Marine and Fisheries department who manage the KUSUKA Card, West Aceh Fishermen as the target of the KUSUKA Card policy, and related institution such as Panglima Laot who collaborate in implementing the KUSUKA card policy in the field.

\section{RESULTS AND DISCUSSION}

Based on field research, it was found that this program which has been running for more than 2 years, has noted 3,148 business actors in the KP sector, but so far only 389 cards have been issued in the printed version. The limited number of printed KUSUKA recipients is of course a problem because in addition to functioning as an identity card, KUSUKA can also be used as a means of insurance and also acts as an ATM and actors can also make loans according to their professional identity at a bank that collaborates with KKP. In this case, the coordinator of extension agents stated that the distribution of print cards was the responsibility of the bank, their job was only to input data to the central server. From this case, it can be seen that there is a problem in the coordination aspect.

In terms of data collection, it can be said that almost $90 \%$ of people who work in the KP sector have been registered in the system, this data can be accessed on the One Data website through the link www.satudata.kkp.go.id on the KUSUKA dashboard. However, as previously stated, in terms of distribution of printed cards, this program is still lacking and of course this is a homework for the KKP to improve coordination with related institutions to immediately distribute KUSUKA cards so that people in need can experience the benefits.

As stated by the fisheries extension worker, so far the society who has been registered in the system will get a temporary KUSUKA card which can be used to get service access until a printed version of the KUSUKA card is distributed. However, the temporary KUSUKA card certainly has limitations in terms of the features it offers, such as it cannot be used as an ATM at Bank so that people cannot fully utilize the KUSUKA function as needed.

\section{Concept of Public Policy Implementation}

In order to provide a complete understanding, before entering into the study of public policy implementation, it is better to first understand what public policy is. There are many opinions from experts regarding the definition of public policy and one of the most popular theories is the theory which states that public policy is whatever the government decides to do or not do something (Dye, 2013).

In line with Dye, Anggara (2018) also defines public policy as a series of interrelated decisions including decisions not to take actions made by parties with authority such as officials/institutions or what is called the government.

Laswell and Kaplan in (Taufiqurokhman, 2014) state that public policy is an activity to achieve goals and values in certain practices that have been previously projected. In addition, Agustino in (Taufiqurokhman, 2014) interpreted public policy more broadly, namely a relationship between government units and their environment.

In addition to the several theories that have been presented, there are still many theories from experts on the definition of public policy, but the whole theoretical debate is mediated by Thomas A. Birkland (2015) who breaks the definition of public policy into several important points, as following:

1. Policy is made to respond problems

2. Policy is made in the public interest

3. Policy aims to achieve the goals and desires of the country

4. Policy is made by the government, even though the basic idea of the policy comes from parties outside the government and interactions with non-government actors

5. Policy is defined and implemented by the government (public) and the private sector (private) with their own styles.

6. Policy is what the government decides to do or not do something.

From the points stated above, it can be concluded that public policy is any activity/step of the government that aims to respond and resolve public problems in order to achieve common goals in the life of the state.

Another defenition that we should understand is the implementation of public policy. Policy implementation is an effort to systematically realize decisions that have been mutually agreed upon in order to achieve a goal. Mazmian and Sebastian in (Wahab, 2008) state that policy implementation is an activity of implementing a predetermined policy. In line with this, Van Metter and Van Horn in (Wahab, 2008) define that policy implementation is a good action taken by stakeholders from the government or the private sector and the community to achieve the goals as set out.

Based on those defenitions, it can be concluded that the implementation of public policy is activity of the government, private sector or society in carrying out joint decisions that have been agreed upon in advance, either in the form of laws or rules and decisions in order to achieve a goal.

\section{Successful policy implementation (Edward III)}

Edward III in (Agustino, 2016) states that the success of policy implementation can be seen from 4 indicators, namely Resources (human, authority, facilities and budget), Communication, Disposition (implementing attitudes) and Bureaucratic Structure. Based on this theory, the findings in the 
field regarding the implementation of the KUSUKA card policy are as follows:

\section{Resources}

In implementing the KUSUKA Card program, the West Aceh Marine and Fisheries Department (DKP) has 8 human resources with at least a bachelor's degree with 1 coordinator among them.

Tabel 1. List of Fishery extension agents in DKP

\begin{tabular}{l}
\hline List of Penyuluh perikanan DKP Aceh Barat \\
\hline Armia, S. St. Pi (Coordinator) \\
Isa Ansani Al Falaqi, S. St. Pi \\
Rosmalinda, S. Pi \\
Rahmad Satria Putra, S. Pi \\
Asrina, S. Pi \\
Rahmatul Husna, S. Pi \\
Erni Susanti, S. Pi., M. Si \\
Ridwan Arazi, S. Kel \\
\hline
\end{tabular}

From the table above, it can be seen that almost all fishery extension workers have educational background in the field of fisheries, only one fishery extension worker has a similar knowledge field. Educational background certainly affects a person's performance on duty, the knowledge that has been worked on before, certainly makes the understanding of fishery extension agents about their work in the fisheries sector more intact so that they can have a positive impact in implementing the KUSUKA card policy.

Performance records of fishery extension agents so far have been able to gather nearly 90\% data on KP sector actors in West Aceh. From these figures, it can be seen that fishery extension agents have almost completed their tasks in data collection process on the KUSUKA card and of course this is a positive achievement even though the fisheries extension agents task is not only limited to data collection, but fisheries extension agents must also provide understanding to the society regarding the KUSUKA card so that the society as a policy target can use the KUSUKA card to get the service as expected. Apart from that, there are still many other tasks that must be done by fishery extension agents, such as socializing KKP policies, mentoring and empowering communities, and so on.

In implementing KUSUKA card policy, fishery extension agents who are spearheading of the KKP in reaching the community are given sufficient authority to implement policies in accordance with the conditions and challenges faced at the location while they work. The KKP have a flexible work system so that fisheries extension agents can find their own solutions to the problems they face. But of course, this flexibility is still limited by the achievement of targets that must be realized.

In providing services, fisheries extension agents are given a special room with simple facilities located at the West Aceh Regency Marine and Fisheries Department to serve people in need. Besides visiting the society in direct to gather data, fisheries extension agents must also stay in the office to provide services to the community who come to the office. In this case, the coordinator has scheduled daily picket for each fishery extension agent until 12 o'clock.
In addition to place facilities, fishery extension agents are also provided with transportation facilities such as motorbike which can be used alternately in order to visit community locations to implement the KUSUKA card policy. This facility is very inadequate when compared to the fisheries extension staff, which numbered 8 people. It is certain that the fisheries extension agents experience problems in dividing the schedule for using this facility according to the needs of each fishery extension agent, especially when it is urgent.

Therefore, improving facilities is something that government must pay attention to so that the performance of fisheries extension agents in implementing the KUSUKA card policy can be better.

besides facilities, the KKP also provides sufficient budget for fishery extension agents in order to implement the KUSUKA card policy. Fishery extension agents are given an operational budget of Rp. 320,000.00 per month to visit the community in the location. In addition, fisheries extension agents are also given additional incentives through the KUSUKA questionnaire of Rp. $5,000.00$ per questionnaire if they are successful in inputting community data into the KUSUKA server on the Satu Data website.

\section{Communication}

Communication in the implementation of the KUSUKA Card policy involves 3 processes, between the KKP and fishery extension agents, fishery extension agents with related institutions (Panglima Laot) and fisheries extension agents with community actors in the KP sector.

Communication between KKP and the fishery extension agents has shown positive results, marked by a good understanding that each fishery extension has in carrying out their obligations as expected. In addition, KKP also maintains communication with fishery extension agents through virtual meetings every week through social media applications as a form of performance evaluation. During the meeting, the fishery extension agents can also ask questions related to things that have not been understood or the obstacles they are facing so that solutions can be found to overcome the problems.

Furthermore, the communication between the fishery extension agents and Panglima Laot. This communication process is established as a form of cooperation where in this process the fishery extension agents ask for help from the Panglima Laot to bridge interactions with the community so that the implementation process of KUSUKA Card becomes easier, and this process experiences obstacles.

Based on findings in the field, Panglima Laot has so far questioned what positive benefits the KUSUKA Card will have for the community. Because Panglima Laot feels that the KUSUKA Card has not had a clear impact on the welfare of the community. This is of course a problem that must be resolved immediately so that the KUSUKA Card can be an effective program in providing a positive impact on society as expected. In this case, the fishery extension agents can convey these aspirations to the KKP so that they can evaluate the KUSUKA Card policy by paying more attention to the aspects of community welfare in it.

Furthermore, the most obvious obstacle can be seen from the communication process between the fishery extension agents and the community. The KUSUKA Card policy failed to transmit properly to policy targets which is society. This is evidenced by 
the fact that almost every community who is an informant does not know the functions of the KUSUKA Card, the community only knows the KUSUKA Card as an identity card and even so far people still call the KUSUKA card a fisherman card that had been issued by the KKP before KUSUKA. In this case, it is clear that there are problems with the socialization aspect. In fact, the KUSUKA card is something that must be understood by the community because in order to access every service and program provided by the KKP, the community must have a KUSUKA card. In other words, people who do not have a KUSUKA card will definitely not be able to get various service facilities and assistance from various programs, either in the form of direct programs from the KKP or programs from the local government.

Unfortunately, there are people who claim do not know the benefits of the KUSUKA card. Therefore, it is hoped that fishery extension agents will be more active in conducting socialization every time they go to the community location to provide understanding and ensure that the community really understands the KUSUKA card policy and what its functions and benefits are.

In addition, the community also confirmed what Panglima Laot had said regarding the problem of the lackness of a positive impact from the KUSUKA card on welfare. The claim made by Panglima Laot and the community is considered very reasonable because the KKP has only provided assistance in the form of fishing gear to 5 groups of fishermen consisting of 10 fishermen per groups. In addition to direct assistance from the KKP, the West Aceh Regency government has also provided assistance in the form of 66 units of 1 GT and 2 GT motorboats, as well as 20 units of Bots containing 2 GT and 3 GT to communities who passed verification process by the district government. However, if it is examined from the aspect of feasibility and adequacy, the amount of assistance is still far from adequate when compared to the number of people in West Aceh who work in the KP sector.

Therefore, the negative stigma that is present in the society's mind is considered very natural. The negative stigma also indicates distrust to the government, in this case the KKP. Therefore, not only the welfare aspect but also the public trust aspect is an important thing that must always be considered so that the concept of good governance in Indonesia can be achieved perfectly especially in KP sector.

\section{Disposition}

The disposition (the attitude of the executor) shows that fishery extension workers tend to support the KUSUKA card policy because it makes it easier for fishery extension workers to focus more on one point only. This is because before the KUSUKA card exist, each service program was not integrated so it was not focused in one database. For example, fisherman identity cards and fisherman insurance cards are made different, causing inefficiency not only in terms of time but also in terms of budget for printing these cards. This will undoubtedly be burdensome for the community in getting services, besides that fisheries extension agents will also face similar obstacles in providing services to the community. Therefore, fishery extension agents welcomed the KUSUKA card policy because this policy also have a positive impact on their performance.

During the research, the authors observed that fishery extension agents showed a friendly and responsive service attitude by using a good emotional approach so that the community felt comfortable in getting services. In addition, the KKP's easy system makes services to the community faster and less complicated so that the community feels the positive impact.

\section{Bureaucratic Structure}

The existence of a clear Standard Procedure (SOP) from the KKP makes implementing the KUSUKA card policy easier. Fishery extension agents stated that they have an easy working system which greatly affects performance. For example, fishery extension agents only need to take a photo of the identity card (KTP) from the society then input the data listed on the KTP into the KUSUKA system on the Satu Data website. The use of KTP is intended to integrate data between related institutions so that problems in electronic-based government governance such as data mismatches between institutions can be resolved. In addition to KTP, other administrative requirements that require data are a certificate from the head and NPWP for people who register in groups (corporations).

The bureaucratic structure of the fishery extension agents in West Aceh is as follows:

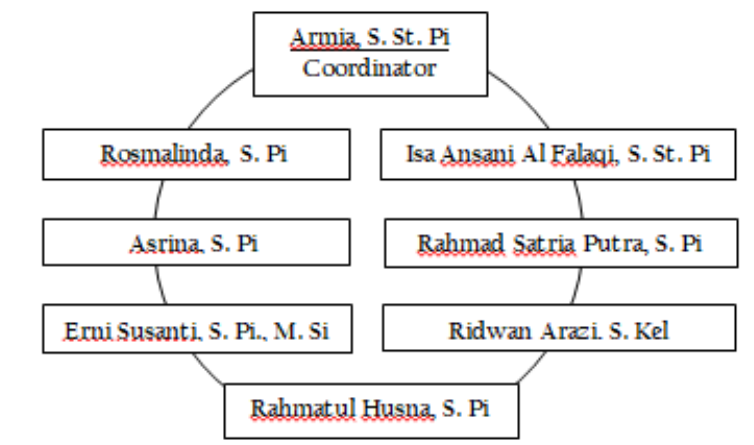

Picture 2. Bureaucracy Structure of Fishery Extension Agents

So far, coordination between fishery extension agents has been going well so that every obstacle faced in the field can be resolved collectively. Each fishery extension agent also understands the main duties and functions (tupoksi) of each so that they can carry out their duties as expected. Besides, not only pay attention to the professional aspects of work, but also teamwork that is built based on good emotional relationships among fishery extension agents so the interaction that happened based on mutual benefit.

\section{CONCLUSION}

Based on the previous discussion, it can be concluded that the implementation of the KUSUKA card policy in West Aceh region is still not good. This is because all indicators of successful policy implementation have not been fulfilled. There are still several problems that must be resolved immediately, such as the lack of facility that can be used by fishery extension agents especially transportation facility and problems in the communication aspect such as the society understanding. In this case, fisheries extension agents have to try harder because there are still many people in West Aceh, especially fishermen who are not highly educated, so it is a little difficult for them to understand the policy issues that often change.

In addition, the lack of positive impacts on the welfare of the society such as lack of government assistance, is also an issue that must be kept in mind. This is directly related to the main objective of any policy issued by the government in a country, which is the welfare of all its people. 


\section{REFERENCE}

Agustino, L. (2016). Dasar-dasar Kebijakan Publik. Bandung: Alfabeta.

Anggara, S. (2018). Kebijakan Publik. Bandung: Pustaka Setia.

Birkland, T. A. (2015). An Introduction to the Policy Process: Theories, Concepts and Models of Public Policy Making. Edisi 3. USA: Routledge

Creswell, J.W. (2016). Research Design Pendekatan metode kualitatif, kuantitatif dan campuran. Edisi 4. Yogyakarta: Pustaka Belajar.

Daniarsyah, D. (2019). Efektivitas Pelaksanaan Kebijakan Program Kartu KUSUKA Pada Kementerian Kelautan dan Perikanan. Journal of Indonesian Public Administration and Governance Studies (JIPAGS), 3(2), 628-643. http://dx.doi.org/10.31506/jipags.v3i2.7552

Dye, T. R. (2013). Understanding Public Policy. Edisi 14. United States of America: Pearson Education.

Taufiqurokhman. (2014). Kebijakan Publik: Pendelegasian Tanggung Jawab Negara Kepada Presiden Selaku Penyelenggara Pemerintahan. Jakarta: Fakultas Ilmu Sosial dan Ilmu Politik Universitas Moestopo Beragama Pers.

Indonesia.go.id. (2019). Kartu Pelaku Usaha Bidang Kelautan dan Perikanan (Kusuka). Cited from https://www.indonesia.go.id/layanan/kependudukan/sosial /kartu-pelaku-usaha-bidang-kelautan-dan-perikanankusuka

Peraturan Menteri Kelautan dan Perikanan No. 16 Tahun 2016 Tentang Kartu Nelayan

Peraturan Menteri Kelautan dan Perikanan No. 39 Tahun 2017 Tentang Kartu Pelaku Usaha Kelautan dan Perikanan

Sugiyono. (2015). Metode Penelitian Pendidikan (Pendekatan Kuantitatif, Kualitatif dan R\&D. Cet 2l. Bandung: Alfabeta.

Tempo.co. (2020). Jokowi Janjikan Tiga Kartu Lagi, Ini Kartu yang Sudah Ada. Cited from https://pilpres.tempo.co/read/l179247/jokowi-janjikan-tigakartu-lagi-ini-kartu-yang-sudah-ada

Wahab, S. (2008). Analisis Kebijakan dari Formulasi ke Implementasi Kebijakan Negara. Malang: Bumi Aksara. 